\title{
Clinico pathological study of right iliac fossa masses and their management
}

\author{
Reddy Venkatapuram M. ${ }^{1}$, Sreeram S. ${ }^{2}$, Prasad Reddy G. V. V. ${ }^{3}$ \\ ${ }^{1}$ Dr. V. Mahidhar Reddy, Associate Professor, ${ }^{2}$ Dr. Sreeram Sateesh, Professor, ${ }^{3}$ Dr. Prasad Reddy G.V.V, Post \\ Graduate, all authors are affiliated with Department of General Surgery, Narayana Medical College, Nellore, Andhra \\ Pradesh, India.
}

Corresponding Author: Dr. Sreeram Sateesh, Professor of Surgery, Department of General Surgery, Narayana Medical College, Nellore, Andhra Pradesh. Mail id: mahiesweb@gmail.com

\begin{abstract}
Aim: The present study aims to study causes, modes of presentation, investigations of choice and management of right iliac fossa masses. Materials and Methods: A prospective study was undertaken on 50 patients presenting with mass in right iliac fossa to surgery outpatient department during the period august 2015 to October 2017. All cases were investigated and managed as per protocol and their data recorded. All the demographic variables were tabulated as per percentage among total cases. Results: In this series out of 50 patients, 23 patients (46\%) diagnosed to have Appendicular mass followed by Ileocaecal TB (20\%), Appendicular abscess (16\%), CA Caecum (12\%) and psoas abscess (6\%). Appendicular pathology is more common in $3^{\text {rd }}$ decade, Ileocaecal TB in $4^{\text {th }} d e c a d e$, CA Caecum and Psoas abscess in $6^{\text {th }}$ decade.In total of 50 patients, $28(56 \%)$ were males and $22(44 \%)$ were females. In the present study pain was the commonest symptom of presentation seen in all cases, fever was present in $78 \%$ cases, vomiting was present in $42 \%$ cases, loss of weight and appetite was present in $24 \%$ cases, constipation was present in $16 \%$ cases, diarrhea was present in $8 \%$ cases, mass per abdomen was present in $26 \%$ cases. Conclusion: The common cause of right iliac fossa mass is of appendicular pathology followed by lleocaecal TB, Carcinoma caecum and psoas abscess in that order, with male preponderance and most of cases falling in $3^{\text {rd }}$ decade.
\end{abstract}

Keywords: Appendicular mass, ileo-caecal tuberculosis, carcinoma caecum, Crohn's disease, amoebic typhlitis, cold abscess

\section{Introduction}

Mass per abdomen has always been considered to be temple of wonders or Pandora's magic box. Mass in the right iliac fossa is a common entity which is frequently encountered in clinical practice requiring skill for diagnosis [1]. The varied etiology of these conditions presents a diagnostic challenge to the surgeon, as appropriately said by Sir Hamilton Bailey "A correct diagnosis is the hand maiden of a successful operation".

Right Iliac Fossa Mass is a common clinical entity encountered in surgical practice [2]. The mass has varied anatomical and etiological origin and requires versatility in its management. This is because the mass may range from benign to most aggressively malignant lesion and touch upon various specialities of surgery like genitourinary surgery, vascular surgery,

Manuscript Received: $20^{\text {th }}$ March 2018

Reviewed: $30^{\text {th }}$ March 2018

Author Corrected: $6^{\text {th }}$ April 2018

Accepted for Publication: $10^{\text {th }}$ April 2018 gynaecological surgery and colorectal surgery [3,4]. Right Iliac Fossa has 8 anatomical entities and six other organs in the neighbourhood whose pathology may extend into this region. Right Iliac Fossa region has Appendix, Caecum, Terminal Ileum, Lymph nodes, Iliac artery and vein, Retroperitoneal connective tissues, Ilio psoas muscle, and Iliac bone. Neighbouring organs and their pathologies which might extend into this region areKidney, Gallbladder, Uterus, Ovaries, Urinary Bladder and Testis. Diagnosis of abdominal mass mainly depends on clinical examination and investigations. The patients are subjected to radiological and pathological investigations $[5,6]$.

Differential diagnosis of mass in the RIF: Parietal Swelling: Parietal swellings are less common in this area. Infrequently, desmoid tumors and burrowing iliac abscess/ appendicular abscess through the abdominal wall into the parietal area are also noticed [7]. 


\section{Original Research Article}

Intra-abdominal swelling from structures in the RIF:

- Appendicular mass

- Appendicular abscess

- Hyperplastic ileocaecal TB [8,9]

- CA caecum

- Crohn's Disease

- Lymph node enlargement

- Iliac abscess

- Ilio psoas cold abscess [10]

- Amoebic typhilitis

- Actinomycosis of caecum and ilium

From structures invading fromneighboring regions:

- Unascended Kidney

- Dropped kidney

- Hydrops gall bladder with enlarged liver

- Tubo-ovarian mass

- Pyosalpinx

- Cyst and abscess of broad ligament

- Fibroid of uterus, ovarian cyst

- Huge diverticulum of urinary bladder

- Undescended testis developing malignancy.

The most common differential diagnosis encountered by surgeons are Appendicular mass, Appendicular abscess, Ileocaecal TB, Right ovarian mass,CA caecum,Right ectopic kidney, Rectus sheath hematoma, Psoas abscess and Amoeboma. In subcontinents, TB has been the main cause of intestinal obstruction and perforation. A set of investigations are ordered to reach a definite diagnosis. These include: CBC, USG Abdomen which are done in all cases. Additional tests like CECT Abdomen, Colonoscopy and biopsy, Diagnostic Laparoscopy, Tumour markers may be needed $[11,12,13,14]$. Appendiceal phlegmon, are commonly managed by conservative treatment till the mass resolves and at a later date interval appendicectomy is done if needed $[15,16,17,18]$. Ileocaecal tuberculous masses are one of the common causes of intestinal obstruction and perforation in subcontinent. they are usually managed by hemicolectomies and resection anastomosis of involved segment $[19,20]$.

\section{Materials and Methods}

Place of Study: Narayana Medical College and Hospital, Nellore.

Type of Study: Prospective study.

Study Period: August 2015 to October 2017.

Sampling method: a cross-sectional study was done with convenient sampling.

Sample collection: 50 cases were selected from surgical OPD which fulfilled the below criteria.

Statistical methods: Results were shown in tables, comparing their numbers and percentages. We used chiquare association test and the $\mathrm{Z}$ test forproportions.

\section{Inclusion Criteria}

- All cases of age more than 12 years that presented during the study period having mass in RIF.

- Patients of both Sex.

- Patients who have also been found to have mass in RIF incidentally on examination and by investigations are included in the study.

\section{Exclusion Criteria}

- Patients having mass in RIF due to gynaecological conditions are excluded.

- Patients with debilitating illness like CRF, ARF, CAD, Liver failure etc are excluded from the study.

\section{Observation and Results}

The results of the study are discussed as following

Table-1: Causes of Right iliac fossa swellings.

\begin{tabular}{|c|c|c|}
\hline Diagnosis & No. of Cases & Percentage \\
\hline Appendicular Mass & 23 & $46 \%$ \\
\hline Ileocaecal TB & 10 & $20 \%$ \\
\hline Appendicular Abscess & 8 & $16 \%$ \\
\hline CA Caecum & 6 & $12 \%$ \\
\hline Psoas Abscess & 3 & $6 \%$ \\
\hline Total & $\mathbf{5 0}$ & $\mathbf{1 0 0 \%}$ \\
\hline
\end{tabular}

In this series out of 50 patients, 23 patients (46\%) diagnosed to have Appendicular mass followed by Ileocaecal TB (10 cases, 20\%), Appendicular abscess ( 8 cases, 16\%), CA Caecum (6 cases, 12\%), psoas abscess ( 3 cases, 6\%). 
Original Research Article

Table-2: Age Wise Distribution of Causes.

\begin{tabular}{|c|c|c|c|c|c|c|c|}
\hline $\begin{array}{c}\text { Age in } \\
\text { years }\end{array}$ & $\begin{array}{c}\text { Appendi - } \\
\text { cular mass }\end{array}$ & $\begin{array}{c}\text { Ileocae - } \\
\text { cal TB }\end{array}$ & $\begin{array}{c}\text { Appendicular } \\
\text { abscess }\end{array}$ & $\begin{array}{c}\text { CA } \\
\text { Caecum }\end{array}$ & $\begin{array}{c}\text { Psoas } \\
\text { abscess }\end{array}$ & $\begin{array}{c}\text { Total no } \\
\text { cases }\end{array}$ & percentage \\
\hline $12-20$ & 5 & 0 & 2 & 0 & 0 & 7 & $14 \%$ \\
\hline $21-30$ & 13 & 1 & 4 & 0 & 0 & 18 & $36 \%$ \\
\hline $31-40$ & 3 & 7 & 1 & 0 & 0 & 11 & $22 \%$ \\
\hline $41-50$ & 1 & 2 & 1 & 2 & 1 & 7 & $14 \%$ \\
\hline$>50$ & 1 & 0 & 0 & 4 & 2 & 7 & $14 \%$ \\
\hline Total & $\mathbf{2 3}$ & $\mathbf{1 0}$ & $\mathbf{8}$ & $\mathbf{6}$ & $\mathbf{3}$ & $\mathbf{5 0}$ & $\mathbf{1 0 0 \%}$ \\
\hline
\end{tabular}

In this series age varies from 14 years to 60 years. Appendicular pathology is more common in $3^{\text {rd }}$ decade, Ileocaecal TB in $4^{\text {th }}$ decade, CA Caecum and Psoas abscess in $6^{\text {th }}$ decade.

Table-3: Diagnosis of RIF Masses.

\begin{tabular}{|c|c|c|c|c|c|c|c|}
\hline Sex & $\begin{array}{c}\text { Appendicular } \\
\text { mass }\end{array}$ & $\begin{array}{c}\text { Ileocaecal } \\
\text { TB }\end{array}$ & $\begin{array}{c}\text { Appendicular } \\
\text { abscess }\end{array}$ & $\begin{array}{c}\text { CA } \\
\text { Caecum }\end{array}$ & $\begin{array}{c}\text { Psoas } \\
\text { abscess }\end{array}$ & $\begin{array}{c}\text { Total no } \\
\text { of cases }\end{array}$ & Percentage \\
\hline Male & 12 & 8 & 4 & 2 & 2 & 28 & $56 \%$ \\
\hline Female & 11 & 2 & 4 & 4 & 1 & 22 & $44 \%$ \\
\hline Total & $\mathbf{2 3}$ & $\mathbf{1 0}$ & $\mathbf{8}$ & $\mathbf{6}$ & $\mathbf{3}$ & $\mathbf{5 0}$ & $\mathbf{1 0 0 \%}$ \\
\hline
\end{tabular}

In total of 50 patients, $28(56 \%)$ were males and $22(44 \%)$ were females

Table-4: Presenting symptoms diagnosis wise

\begin{tabular}{|c|c|c|c|c|c|c|c|c|}
\hline $\begin{array}{c}\text { SL } \\
\text { No }\end{array}$ & Diagnosis & Pain & Fever & Vomiting & $\begin{array}{c}\text { Loss of } \\
\text { appetite and } \\
\text { weight loss }\end{array}$ & Constipation & Diarrhea & Mass \\
\hline 1 & $\begin{array}{c}\text { Appendicular } \\
\text { mass }\end{array}$ & 23 & 18 & 15 & 0 & 0 & 2 & 5 \\
\hline 2 & Ileocaecal TB & 10 & 10 & 6 & 6 & 6 & 0 & 3 \\
\hline 3 & $\begin{array}{c}\text { Appendicular } \\
\text { abscess }\end{array}$ & 8 & 8 & 6 & 0 & 0 & 2 & 2 \\
\hline 4 & CA caecum & 6 & 0 & 0 & 6 & 2 & 0 & 3 \\
\hline 5 & Psoas abscess & 3 & 3 & 0 & 0 & 0 & 0 & 3 \\
\hline & Total & $\mathbf{5 0}$ & $\mathbf{3 9}$ & $\mathbf{2 1}$ & $\mathbf{1 2}$ & $\mathbf{8}$ & $\mathbf{4}$ & $\mathbf{1 3}$ \\
\hline
\end{tabular}

In the present study pain was the commonest symptom of presentation seen in all cases, fever was present in $78 \%$ cases, vomiting was present in $42 \%$ cases, loss of weight and appetite was present in $24 \%$ cases, constipation was present in $16 \%$ cases, diarrhea was present in $8 \%$ cases, mass per abdomen was present in $26 \%$ cases

Table-5: Endoscopy and Imaging as per diagnosis

\begin{tabular}{|c|c|c|c|c|c|}
\hline Sl.No & Diagnosis & USG & Colonoscopy & CT Scan & Diagnostic Laparoscopy \\
\hline 1 & Appendicular Mass & 23 & 0 & 0 & 0 \\
\hline 2 & Ileocaecal TB & 10 & 0 & 0 & 0 \\
\hline 3 & $\begin{array}{c}\text { Appendicular } \\
\text { Abscess }\end{array}$ & 8 & 0 & 0 & 0 \\
\hline 4 & CA Caecum & 6 & 6 & 6 & 0 \\
\hline 5 & Psoas Abscess & 3 & 0 & 0 & $\mathbf{2}$ \\
\hline & Total & $\mathbf{5 0}$ & $\mathbf{6}$ & $\mathbf{6}$ & 0 \\
\hline
\end{tabular}

In the present study Usg abdomen is done in all cases. Colonoscopy is done in all cases of CA Caecum and multiple biopsies are taken. CECT Abdomenis done in all case of CA Caecum for tumor staging. Diagnostic laparoscopy isdone in 2 case $(20 \%)$ of Ileocaecal TB. 
Original Research Article

Table- 6: Treatment as per diagnosis.

\begin{tabular}{|c|c|c|c|}
\hline Diagnosis & No. of cases & Conservative management & Surgery \\
\hline Appendicular Mass & 23 & 23 & 0 \\
\hline IleocaecalTB & 10 & 4 & $\begin{array}{c}\text { 6(limited resection+ileo- } \\
\text { ascending anastomosis) }\end{array}$ \\
\hline Appendicular Abscess & 8 & 0 & 8(Intr/extra peritoneal drainage) \\
\hline CA caecum & 6 & 0 & $\begin{array}{c}\text { 6(radical right hemicolectomy } \\
+ \text { ileo-transverse anastomosis) }\end{array}$ \\
\hline Psoas Abscess & 3 & 0 & 3 (aspiration/drainage) \\
\hline Total & $\mathbf{5 0}$ & $\mathbf{2 7}$ & $\mathbf{2 3}$ \\
\hline
\end{tabular}

In the present study 27 cases (54\%) are managed conservatively and 23 cases (46\%) are treated surgically. All the cases of appendicular mass are managed conservatively. 4 cases of Ileocaecal TB are managed by medical management and rest all the cases are treated surgically.

Table-7: HPE report of the resected specimens

\begin{tabular}{|c|c|c|c|}
\hline Preop diagnosis & No of surgeries & Surgery & HPE report \\
\hline Appendicular pathology & 15 & Interval appendectomy & Appendicitis \\
\hline Ileocaecal TB & 6 & $\begin{array}{c}\text { Limited resection with ileo- } \\
\text { ascending colon anastamosis }\end{array}$ & Ileocaecal TB \\
\hline CA. Caecum & 6 & Right radical hemicolectomy & $\begin{array}{c}\text { Well differentiated } \\
\text { adenocarcinoma }\end{array}$ \\
\hline
\end{tabular}

All patients who underwent interval appendectomy, HPE report came as chronic appendicitis. All patients of CA Caecum underwent right radical hemicolectomy and HPE report came as well differentiated adenocarcinoma. 6 cases of Ileocaecal TB underwent limited resection ileo- ascending colon anastomosis and HPE report of resected specimens are suggestive of Ileocaecal TB.

\section{Discussion}

The present study was carried out to evaluate various diseases presenting as mass in the right iliac fossa. Several variables like age, sex, incidence, clinical presentation, type of investigation needed, mode of treatment and histopathology of resected specimens etc. were studied in all the selected cases.

About 50 patients who presented with right iliac fossa mass were selected for this study during the period August 2015 to October 2017 at Narayana medical college and hospital Nellore.

After detailed history, thorough clinical examination and relevant investigations a proper diagnosis was arrived at. Whether it was conservative or surgical,a standard treatment was given depending upon the diagnosis. following are the observations and inferences which we concluded. In our study appendicular pathology (appendicular mass and abscess) was the most common disease encountered followed by Ileocaecal tuberculosis, carcinoma caecum and Psoas abscess in that order. The same observation was found in a study conducted at victoria hospital affiliated to Bangalore Medical college and research institute by shashikala $\mathrm{V}$ et al [21]. In the present study Pain abdomen, followed by fever and vomiting were the predominant symptoms. According to S K Shetty, M Shankar, pain abdomen was present in almost all cases, fever in $93 \%$ of cases and vomiting in about $50 \%$ of cases [22].

In the present study 8 cases $(16 \%)$ are diagnosed asappendicular abscess. The highest number of cases are found in third decade $(50 \%)$. The patients age ranged from 14 to 41 years, with male to female ratio being 1:1. According to Edward L. Bradley and James lsaacs, age ranges from 4-83 years $(40.7+-2.7 \mathrm{yrs})$, male to female ratio of appendicular abscess is 1.26:1[23,24]. According to Philip Abraham and Ferosh P. Mistry, tuberculosis of gut is common in the ileocaecal region (55.85\% of cases) and the prevalence is approximately equal in males and females. In the 


\section{Original Research Article}

present study 10 cases $(20 \%)$ are diagnosed as Ileocaecal Tuberculosis [25,26,27]. The highest number of cases are found in third decade $(70 \%)$, with male to female ratio being $4: 1$. According to $\mathrm{S}$. K. Bhansali, $2 / 3 \mathrm{rd}$ of patients were in 4th-5th decades [28]. According to Prakash et al.the highest incidence of this disease was found in the age group of 20-40 years[29].

In the present study 6 patients arediagnosed to have CA Caecum, the highest number of cases are found in $6^{\text {th }}$ decade $(66.67 \%)$ followed by $5^{\text {th }}$ decade $(33.33 \%), 4$ patients $(66.6 \%)$ are females and 2 patients $(33.3 \%)$ are males with male: female ratio being 1:2 [30,31].

S K Shetty et alreported $87 \%$ cases of CA Caecum were more than 40 years of age and more common in females[32].According to the studies of Smiddy and Goligher (1957) and D Gomez et al (2004), the incidence of carcinomas in the right colon (caecum and ascending colon) is $25-31 \%$, and in the left colon (descending colon and sigmoid) is $50-69 \%[33,34]$.

\section{Conclusion}

Appendicular pathology continues to be the most common cause of right iliac fossa masses followed by ileocaecal TB, Carcinoma caecum and psoas abscess in that order, at least in this geographical location. Majority of the patients involved are in 3rd decade followed by 4 th decade with slight male predominance. conservative treatment for appendicular masses and extra peritoneal drainage for appendicular abscesses are found to be effectiveprocedures.

\section{What this study contributes}

Results of our study strongly concur with the existing knowledge of right iliac fossa masses in particular appendicular phlegmon, in several of its factors. our study emphasizes the successful role of conservative treatment in the management of appendicular phlegmon.

Conflict of interest: None declared.

Funding: Nil, Permission from IRB: Yes

\section{References}

1. Junior Sunderesh N, Narendran .S , Ramanathan .M, evaluation of pathological nature of RIF mass and its management. J Biomed science resource 2009; 1(1): 55-58.

2. Dnyanmote AS, Sinha N, Chavan S, Sable S.Clinico pathological study of RIF mass. Web med central general Surgery 2014;5(11).
3. Carpenter SG, Chapital AB, Merritt MV, Johnson DJ. Increased risk of neoplasm in appendicitis treated with interval appendectomy: single-institution experience and literature review. Am Surg. 2012 Mar; 78 (3): 339-43.

4. Furman MJ, Cahan M, Cohen P, Lambert LA. Increased risk of mucinous neoplasm of the appendix in adults undergoing interval appendectomy. JAMA Surg. 2013 Aug;148(8):703-6. doi: 10.1001/jamasurg. 2013. 1212.

5. Madhushankar L, Satish Kumar R, Sanjay SC. Roll of USG in preoperative evaluation of RIF mass. Journal of evolution of Medical and Dental sciences 2013;2 (126): 9030-36.

6. Richardson NG, Heriot AG, Kumar D, Joseph AE. Abdominal ultrasonography in the diagnosis of colonic cancer. Br J Surg. 1998 Apr; 85 (4):530-3. DOI:10. 1046/j. 1365-2168.1998.00637.x

7. Teixeira PG, Demetriades D. Appendicitis: changing perspectives. Adv Surg. 2013;47:119-40.

8. Bakhshi G D, Deshpande S, Jadav K V, Shenoy SS, Yadav R. Abdominal kochs: An analysis - an Indian perspective. International journal of medical and applied sciences 2013;2(3):248-254.

9. Dutta gupta A. K., Intestinal tuberculosis, Indian journal of surgery, 1958,20:396-400.

10. Bartolo DCC. psoas abscess in bristol - a 10 year review. Int. J. colorectal Dis., 1987, 2:72-6.

11. Kedar RP, Shah PP, Shivde RS, Malde HM. Sonographic findings in gastrointestinal and peritoneal tuberculosis. Clin Radiol. 1994 Jan; 49 (1): 24-9.

12. Lee DH, Ko YT, Yoon Y, Lim JH. Sonographic findings of intestinal tuberculosis. $\mathrm{J}$ Ultrasound Med. 1993 Sep;12(9):537-40.

13. Pettengelet al. Colonoscopic features of early tuberculosis - a report of 11 cases. S.AF.Med J, 1991, march. 2:79(5):279-280.

14. Wall SD, Fisher MR, Amparo EG, et al. Magnetic resonance imaging in the evaluation of abscesses. AJR Am J Roentgenol. 1985 Jun;144(6):1217-21.

15. Bhansali S K. Abdominal Tuberculosis: A clinical analysis of 135 cases. Indian journal of surgery, 1968 , $30: 72-76$. 


\section{Original Research Article}

16. Deelder JD, Richir MC, Schoorl T, Schreurs WH. How to treat an appendiceal inflammatory mass: operatively or nonoperatively? J Gastrointest Surg. 2014 Apr;18(4):641-5. doi: 10.1007/s11605-014-24601. Epub 2014 Feb 4.

17. Zhang HL, Bai YZ, Zhou X, Wang WL. Nonoperative management of appendiceal phlegmon or abscess with an appendicolith in children. J Gastrointest Surg. 2013 Apr; 17(4):766-70. doi: 10.1007/s11605013-2143-3. Epub 2013 Jan 12.

18. Thomas DR. Conservative management of the appendix mass. Surgery. 1973 May;73(5):677-80.

19. Anand S.S. Hypertrophic ileocaecal tuberculosis in India with a record of 50 Hemicolectomies. Annals of royal college of surgeons, 1956,19:205-222.

20. Pujari BD. Modified surgical procedures in intestinal tuberculosis.Br J Surg. 1979 Mar;66(3):180-1.

21.Shashikala V et al / International Journal of Biomedical and Advance Research 2016; 7(8): 388-392.

22. S K Shetty, M Shankar. A Clinical Study Of Right Iliac Fossa Mass. The Internet Journal of Surgery. 2013 Volume 30 Number 4.

23. Bradley EL 3rd, Isaacs J. Appendiceal abscess revisited. Arch Surg. 1978 Feb;113(2):130-2.

24. Walsh TR, Reilly JR, Hanley E, et al. Changing etiology of iliopsoas abscess. Am J Surg. 1992 Apr;163 (4):413-6.

25. Philip Abraham and Ferosh P. Mistry, "Tuberculosis of the Gastrointestinal Tract”, Ind J Pub,1992,39,251.
26. Prakash ATM. Intestinal tuberculosis - 10 years review. Indian Journal of surgery, 1978, Feb March; 56-65.

27. Prakash A, Sharma LK, Koshal A, et al. Ileocaecal tuberculosis. Aust N Z J Surg. 1975 Nov;45(4):371-5.

28. Bhansali, S.K. (1978) The challenge of abdominal tuberculosis in 310 cases. Ind. J. Surg., 40, No. $2 \& 3$, 65-77.

29. Prakash, Atm. (1978) Intestinal tuberculosis. 18 Year Review. Ind. J. Surg. Vol. 40, No. 2 \& 3, p. 56-64.

30. Amin MA, Khan MA, Ayub M, et al. Delay in the diagnosis and prognosis of caecal carcinoma--a study of 20 cases. J Ayub Med Coll Abbottabad. 2001 AprJun;13(2):28-31.

31. Mc Dermatt FT. Comparative results of surgical management of single carcinoma of the colon and rectum: a series of 1939 patients managed by a single surgeon. Br J Surg, 1981; 68:850-855.

32.S K Shetty, M Shankar. A Clinical Study Of Right Iliac Fossa Mass. The Internet Journal of Surgery, 2013, vol.30,no.4.

33.Goligher JC, Smiddy FG. The treatment of acute obstruction or perforation with carcinoma of colon and rectum. Br J Surg. 1957:270.

34. Gomez D, Dalai Z, Raw E, Roberts C, Lyndon PJ. Anatomical distribution of colorectal cancer over 10 year period in a district general hospital: is there a true rightward shift? Postgraduate Med J 2004; 80: 667669.

\section{How to cite this article?}

Reddy Venkatapuram M, Sreeram S, Prasad Reddy G. V. V. Clinico pathological study of right iliac fossa masses and their management. Surgical Update: Int J surg Orthopedics.2018;4(4):133-138.doi:10.17511/ijoso.2018.i04.01. 